\title{
Analysis and Comparison of the Factors Influencing Worldwide Four Kinds of Vegetable Oil Trade: Based on Gravity Model
}

\author{
Jiayou Wang \\ College of Economics and Management, China Agricultural University, Beijing, China \\ Email: jiayou1214@163.com \\ Received 26 January 2016; accepted 19 February 2016; published 22 February 2016 \\ Copyright (C) 2016 by author and Scientific Research Publishing Inc. \\ This work is licensed under the Creative Commons Attribution International License (CC BY). \\ http://creativecommons.org/licenses/by/4.0/

(c) (7) Open Access

\begin{abstract}
This paper analyzes the motivator and obstructive elements influencing trade of four kinds of vegetable oil by using the generalized gravity model. The balanced panel dataset used in the analysis includes bilateral trade spans 80 countries for the period from 2000 to 2013. Empirical results reveal that importer's GDP plays a leading role to boosting four kinds of vegetable oils trade and there is a positive impact of oilseeds trade on vegetable oil trade and bilateral exchange rate has nothing to do with the vegetable oil trade.
\end{abstract}

\section{Keywords}

Bilateral Trade, Vegetable Oil, Gravity Model

\section{Introduction}

Agricultural sector was still under high protection after several rounds of multilateral trade negotiations until the Uruguay Round (UR). The UR raised the Agreement on Agriculture (AA) to begin the process of liberalizing trade in agricultural food market in 1994 [1]. A zero-for-zero proposal for oilseed products with the aim to reducing agricultural food trade barrier was not adopted at the end the UR although it received strong support from industry [2]. Mainly to further reduce trade barriers and open more free markets in agriculture sector which would benefit all countries, World Trade Organization (WTO) launched a ministerial conference in Doha in 2001. However, it failed to reach an agreement until the end of 2005. Agriculture is remaining heavily protected because countries were looking for respective special interests of their own. In order to protect domestic crushing and refining industries, taxes have been levied on vegetable oils by some countries [3]. India, for example, has designated several agricultural products not to be liberalized which were including oilseeds product [4]. 
The termination of the Doha Round (DR) and wishes for greater openness in agricultural market, has led many countries to seek out the "the second best" bilateral free-trade agreements (FTAs) to alternate and complete multilateral trade agreement. Economists are always required by national governments and international organizations to quantify multiple types of trade agreements, complex policy instruments and differential policy treatment to measuring the perceived opportunities from trade liberalization. Besides, the value of export supply and import demand, and geographical location are also important factors which influence the bilateral, regional and multilateral international trade. With the development in computational facility, the computable general equilibrium (CGE) model has become a main horse in the field of trade for estimating benefits from bilateral (e.g., Robinson et al., 1993) [5], regional (e.g., Park, 2006) [6] and multilateral (e.g., Baier et al., 2004) [7] trade. As an alternative of CGE model, gravity model has gained mature theoretical foundations and acquired a solid reputation of good fitting in the trade literature, which can be identified as a credible econometric analysis way to better understand the nature of cross border trade in recent years. Besides, as key factors of trade, policydriven and socioeconomic variables can be estimated by gravity model.

With the rapid growth in world population and income, international trade for vegetable oil is expanding at a significant pace. In 1995, bilateral trade of vegetable oils in worldwide was about 49 million tons. Bilateral trade had increased 1.79 times to 137 million tons in $2014^{1}$. Now, vegetable oil has become one of the largest sectors in international trade. There are four kinds of vegetable oils trade combines palm oil, rapeseed oil, soybean oil and sunflower seed oil, which account for $85 \%$ of the world's vegetable oil production and $90 \%$ of world's vegetable oil trade. In 21st century, worldwide palm oil trade is the largest kind of vegetable oil trade, which account for $55 \%$ of total vegetable oils trade because its price advantage. Soybean oil, sunflower seed oil and rapeseed oil account for $20 \%, 13 \%$ and $12 \%$ of the total vegetable oils trade respectively. There is an increasing gravity studies which explicitly estimate the impact of determinants of trade on in certain kinds of vegetable oil. Pujiati et al. (2014) examined the effect of the Regional Trade Agreement on the trade flows of palm oil by analyzed with gravity model [8]. Zahniser et al. (2002) employed a series of modified gravity models to explore individual commodities changes which are including soybean oil and sunflower seed oil in US agricultural exports to the members of NAFTA and MERCOSUR [9]. Kavallari et al. (2010), Vlontzos and Duquenne (2008) employed a gravity model to estimate the influencing factors which affecting olive oil trade in Greek and German separately [10] [11]. Focusing on the EU Canola Oil trade market, Röttgers et al. (2009) analyzed European import and its drivers with developing countries by using gravity analyses [12]. However, from the existing research in agricultural sector, for analyzing different drivers that either deter or aid partner trade, there is a relative paucity of gravity studies which compare different kinds of vegetable oils.

To fill this gap, we employ a generalized gravity framework to estimate the potential role of drivers, such as bilateral FTAs, inequality variable and historical and cultural linkages, on trade flows in the four main kinds of vegetable oils. In order to improve the quality of the model estimates, this study employs the balanced panel dataset spans 80 countries for the period from 2000 to 2013. The existence of zero-trade flows in data on bilateral vegetable oil trade has pushed researchers to seek solutions. The Poisson pseudo-maximum likelihood (PPML) estimator introduced by Gourieroux et al. (1984), can readily handle zero observations and heteroskedasticity which have been recognized to affect gravity-type estimations. Therefore, based on recent methodological advances in the gravity literature, we employ PPML approach to estimate the gravity model.

The remainder of the article is organized as follows: Section 2 reviews the relevant literature about the evolving gravity framework. Section 3 presents the methodology of the empirical model. Firstly, it introduces the characteristic of the PPML estimation specifically. Secondly, it presents the empirical model and explains various economic theories behind those influencing factors. Lastly, it identifies the source of data used in the empirical analysis and the method to solve the discrepancy in bilateral trade data. Section 4 presents empirical results and analyzes and compares the possible reasons for results which the factors influencing the trade of the four main kinds of vegetable oils. Section 5 summarizes and concludes.

\section{Conceptual Framework}

A law called the "gravity equation" posits that bilateral trade value between partner countries is a function of the size of two countries and distance, a proxy for the transaction costs [13] [14]. Initially the gravity equation lacked any sound theoretical foundation though it had extraordinary stability to explain bilateral trade flows. At

${ }^{1}$ Data is calculated by source from FAO. 
that time, classical models of international trade ware the Ricardian model and the Heckscher-Ohlin (HO) model which couldn't provide any micro foundation for the gravity model.

Anderson (1979) developed the first theoretical basis—general-equilibrium foundation for gravity model. He pointed out that goods were differentiated by their origin (the so-called Armington assumption) and where consumers have different preferences for different goods [15]. It implies that national income is the sum of the specific commodity demand of the country's production at home and abroad, which is saying that import and export will be increasing when the country size is larger. The relationship between gravity model and trade theory was specified by Helpman and Krugman (1985), they clarified the connection between the HO model and increasing returns explanation of trade [16]. Bergstrand (1985 and 1989) was influenced by monopolistic competition theory which was developed by Krugman in 1980 and overcame the defect of Armington assumption, indicated that two homogeneous countries trade different commodities because preference of consumers is variety [17] [18]. Bergstrand (1989) also demonstrated that inter-industry and intra-industry trade can be both applied to gravity model. Deardorff (1998) showed that the gravity model can be derived from explanation of traditional factor-proportions of trade and can accommodate competitive and monopolistic-competitive models of trade [19]. Evenett and Keller (2002) found that more realistic results would be generated in analytical frameworks which allows for imperfect specialization than those based on perfect specialization [20].

The general formulation of gravity model is

$$
X_{i j}=G S_{i} M_{j} \varphi_{i j}
$$

where $X_{i j}$ is the value of exports from $i$ to $j . S_{i}$ is the exporter's size that represent its capacity to supply goods. $M_{j}$ is the importer's size that denotes its ability to demand commodities. $G$ does not depend on $i$ or $j$ such as the level of world liberalization. Lastly, $\varphi_{i j}$ represents the degree of convenience exporter $i$ to access of importer $j$, which is the inverse of bilateral trade costs.

More recently, the particularly important contribution of research concerning the theoretical foundation in the gravity model is Anderson and van Wincoop's (2003) paper, which formalized a paradigm for following econometric gravity work [21]. In their gravity framework, as a central equilibrating role, prices is showing bilateral resistances which the exporter and the importer confronting. And prices differ between regions because of trade costs. Controlling for relative trade costs is crucial for a specified gravity model. The results of their theory show that bilateral trade is decided by relative trade costs, not simply by the absolute trade costs between trading partners. Anderson and van Wincoop ( $\mathrm{AvW}$ ) model is derived from a demand function. They employed the constant-elasticity-of-substitution (CES) expenditure system and derive a practical model which trade costs connect to both bilateral and multilateral resistances. AvW show that the gravity equation can be written as follows:

$$
X_{i j}=\left(\frac{Y_{i} Y_{j}}{Y}\right)\left(\frac{T_{i j}}{P_{i} P_{j}}\right)^{1-\sigma}
$$

where

$$
\begin{gathered}
P_{i}^{1-\sigma}=\sum_{j} P_{j}^{1-\sigma} \theta_{j} T_{i j}^{1-\sigma}, \forall i, \\
P_{j}^{1-\sigma}=\sum_{i} P_{i}^{1-\sigma} \theta_{i} T_{i j}^{1-\sigma}, \forall j,
\end{gathered}
$$

and where $X_{i j}$ is exports from country $i$ to country $j$; $Y_{i}$ and $Y_{j}$ are the GDP of country $i, j$ respectively; $Y$ is the GDP of the world; $T_{i j}$ is bilateral trade costs; $\sigma$ is the elasticity of substitution between the countries' commodities; $P_{i}$ and $P_{j}$ are price indices which are dependent of trade barriers $\left(T_{i j}\right)$, regard as "multilateral resistance" terms. $P_{i}$ captures "outward multilateral resistances" that depicts $i$ 's the average trade resistance with its demanding countries; $P_{j}$ embodies "inward multilateral resistances" that represents the average trade resistance between $j$ and its exporting partners; and $\theta$ represents income shares. Generally, $P_{i}$ and $P_{j}$ are low if a country is remote from world market, and the lever of remoteness is determined by physical elements such as distance from large markets.

From the Equations (2)-(4), we can see that when the country size has been controlled, the value of bilateral trade is determined by trade barriers, which should include aid factors as well as deter elements. Also, bilateral trade not only depends on the bilateral drivers, but also on multilateral drivers. Empirically, these unobserved and hard to quantified multilateral factors are proxied by country-specific dummies [22] [23]. The adjacency dummy has been proved as an important factor to the extended gravity model, Frankel et al. (1993) included 
common language to the gravity equation as social extensions [24]. Adding colonial links dummy to gravity model reveals historical ties is a notable element which influences trade. Moreover, some gravity related researches focus on the impact of different free trade agreements (FTAs) on trade.

\section{Methodology}

\subsection{The PPML Estimation}

The Poisson maximum-likelihood (ML) estimator is applied by count data models with the discrete dependent variable, probability mass is in distribution of nonnegative integer values [25]. The pseudo Poisson maximum likelihood (PPML) estimator, another Poisson estimator, is also consistent when it is applied to nonnegative continuous values [26] [27]. In the Poisson model, the trade value between partner countries follows a Poisson distribution with probability:

$$
P \operatorname{Prob}=\operatorname{Pr}\left[X_{i j}\right]=\frac{\mathrm{e}^{-\mu_{i j}} \mu_{i j}^{X_{i j}}}{X_{i j} !} \quad X_{i j}=0,1, \cdots,
$$

where $\mu_{i j}$ is the rate parameter, which is a function of the independent variables; the conditional mean of bilateral trade is $E\left[X_{i j}\right]=\mu_{i j}$ and the variance $\operatorname{Var}\left[X_{i j}\right]=\mu_{i j}$.

Based on the empirical research about gravity model, it is often believed that PPML is a robust approach which could deal with heteroscedasticity and biases of the zero trade values in panel data [28]. Heteroskedasticity is recognized as when random error term possesses different variances in regression function. If we use the traditional ordinary least squares (OLS) to estimate the model, the parameter estimator will not be effective or even asymptotically efficient; and it is also unable to test significance of parameters. An alternative approach, suggested by Santos Silva and Tenreyro (2006) and based on methodological advances, is called pseudo Poisson maximum likelihood (PPML) estimation method. The PPML estimation will provide better result than OLS method in processing inconsistent bias in the presence of heteroskedasticity [28].

Examining our panel data, about 79\%, 85\%, $80 \%$ and $79 \%$ of observations in trade value of palm oil, rapeseed oil, soybean oil and sunflower seed oil are found to exhibit zero values separately. There are two common ways of dealing with this problem by using the OLS log-linear specification of the gravity equation: firstly, deleting all observation with zero values; secondly, replacing zero observations by adding a small number [29]. However, these approaches have shortcomings in both theoretical and econometric aspects. Firstly, zero values in the dependent variables don't mean zero observations are missing, and it represents true absence of trade. Dropping zero values may ignore valuable information [30]. It can lead to biased results when these zero-valued flows are non-randomly distributed [26]. Secondly, Burger et al. (2009) considered that adding a small constant to zero values is lacking rational theoretical foundation. Santos Silva and Tenreyro (2006) provided simulation evidence that the PPML is well behaved in handling zero-trade values to overcoming the limitations of the log-linearization. Even when the proportion of zeros in the sample is very large (conditional variance has higher proportions to the conditional mean), the PPML estimator is consistent and generally performed well [31].

\subsection{Final Model Specification}

According to the objective of this research, the final structure of the empirical gravity model employed in this study uses panel data, introduces some new independent variables, and is estimated by PPML approach, leading to the following specification equation of extensive gravity model:

$$
\begin{aligned}
X_{i j t_{-} p}= & \exp \left(\alpha_{1}+\mu_{i j t 1}+\beta_{7 b} F_{i j A_{i j t}}+\beta_{8 b} L A N G_{i j}+\beta_{9 b} C O L_{i j}+\beta_{10 b} B O R_{i j}\right) \\
& \times G D P_{i t}^{\beta 1 b} G D P_{j t}^{\beta 2 b} D I S_{i j}^{\beta 3 b} I N C_{i j t}^{\beta 4 b} R A T E_{i j t}^{\beta 5 b} S E E D_{i j t}^{\beta 6 b} \\
X_{i j t_{-} r}= & \exp \left(\alpha_{2}+\mu_{i j t 2}+\beta_{7 c} F T A_{i j t}+\beta_{8 c} L A N G_{i j}+\beta_{9 c} C O L_{i j}+\beta_{10 c} B O R_{i j}\right) \\
& \times G D P_{i t}^{\beta 1 c} G D P_{j t}^{\beta 2 c} D I S_{i j}^{\beta 3 c} I N C_{i j t}^{\beta 4 c} R A T E_{i j t}^{\beta 5 c} S E E D_{i j t}^{\beta 6 c} \\
X_{i j t_{-} s}= & \exp \left(\alpha_{3}+\mu_{i j t 3}+\beta_{7 d} F T A_{i j t}+\beta_{8 d} L A N G_{i j}+\beta_{9 d} C O L_{i j}+\beta_{10 d} B O R_{i j}\right) \\
& \times G D P_{i t}^{\beta 1 d} G D P_{j t}^{\beta 2 d} D I S_{i j}^{\beta 3 d} I N C_{i j t}^{\beta 4 d} \operatorname{RATE}_{i j t}^{\beta 5 d} S E E D_{i j t}^{\beta 6 d}
\end{aligned}
$$




$$
\begin{aligned}
X_{i j t_{-} f}= & \exp \left(\alpha_{4}+\mu_{i j t 4}+\beta_{7 e} F T A_{i j t}+\beta_{8 e} L A N G_{i j}+\beta_{9 e} C O L_{i j}+\beta_{10 e} B O R_{i j}\right) \\
& \times G D P_{i t}^{\beta 1 e} G D P_{j t}^{\beta 2 e} D I S_{i j}^{\beta 3 e} I N C_{i j t}^{\beta 4 e} \operatorname{RATE}_{i j t}^{\beta 5 e} S E E D_{i j t}^{\beta 6 e}
\end{aligned}
$$

where subscript $t$ refers to the year, $i$ to the exporting country, and $j$ to the importing country. $X_{i j t \_p}, X_{i j t_{-}}, X_{i j t_{-}}$, $X_{i j t \_}$are the value of the bilateral trade flow between $i$ and $j$ for palm oil, rapeseed oil, soybean oil and sunflowersee oil separately.

$G D P_{i t}$ and $G D P_{j t}$, representing exporter's GDP, importer's GDP respectively, are economic attractors. As planets are mutually attracted in proportion to their sizes which defined by Newtonian theory of gravitation, trade between countries is in proportion to their GDPs. $G D P_{i t}$ and $G D P_{j t}$ are signifying the supply capacity of exporting and demand capacity of importing respectively. The bigger the economic scales of exporter and importer, the greater the potential ability to export and import, the bilateral trade flow is larger.

Geographic factors include the distance between the two trading partners $\left(D I S_{i j}\right)$ and common borders $\left(B O R_{i j}\right)$. Distance reveals physical transport costs, which is the barrier factor to trade. When a common boundary exists on both trading partners who have a chance to exchange information easily, bilateral trade flow will increase while the trade costs decline.

In terms of historical and cultural linkages, common language $\left(L A N G_{i j}\right)$ and colonial heritage $\left(C O L_{i j}\right)$ are incorporated. Both factors are related to lower trade costs as they facilitate communication during economic transactions and often reflect cultural similarity, and can reduce the fixed costs of entering a new market due to the established historical trade relationship.

In addition, as an institutional factor, membership of a FTA $\left(F T A_{i j t}\right)$ is inserted to the gravity model following Francois and Manchin (2006) [32]. Free trade agreements have the positive effect to lower trade costs between memberships. The FTAs was a good opportunity to increase profit as it helped to increase market share and tariff reduction [33].

The inequality variable $\left(I N C_{i j t}\right)$ measures difference in per-capita income between trading partners. According to the theory of preference similarity by Linder (1961), the more similar two country's level of economic development, the more conducive to promote the development of trade between them [34]. Income inequality is intended to capture perspective of demand to seek the answers to explain that demand can be the cause of trade. Trading partners with high income inequality import more luxuries while those with low income inequality import more necessities [35]. Also, differential tastes and preferences impacts trade which $I N C_{i j t}$ can reveal. Countries whose consumers have similar per capita incomes will increase their trade because each of them produces differentiated products primarily to meet their own consumers’ preferences first.

Moreover, bilateral exchange rate $\left(R A T E_{i j t}\right)$ is complemented to the equation. According to economic theory of money neutrality, exchange rate is unchanged because money supply will not affect interest rate under the condition of long time. However, exchange rate is changeable in many macroeconomic empirical evidences. The change of exchange rate will affect the relative price on both sides of trade. Since this gravity model uses the bilateral exchange rate which is the exporter currency against the importer currency, with other conditions unchanged, bilateral exchange rate depreciation means that importer need to pay a higher currency price, which will result in imports to drop; also exporter will have a lower price in its goods which will cause exports to increase. So bilateral trade exchange rate is related to export supply and import demand but the influence direction is uncertain.

Finally, we include the value of the bilateral trade flow for four main vegetable oilseeds $\left(S E E D_{i j t}\right)$ (palm oilseeds, rapeseed oilseeds, soybean oilseeds and sunflower oilseeds) to this gravity model. According to microeconomics theory, when the relative price of a commodity changes and consumers under the condition of constant real income, substitution effect will come from commodity demand change. There is a substitute relationship between vegetable oils and vegetable oilseeds because most import vegetable oilseeds are crushed into vegetable oils for use. Therefore, to a certain extent, the increase of vegetable oilseeds import will instead of vegetable oils imports and further decrease vegetable oils trade.

$\alpha_{1}-\alpha_{4}$ is a common intercept, $\mu_{\mathrm{ijt} 1}-\mu_{\mathrm{ijt} 4}$ are the error term. $\beta_{1 x}-\beta_{10 \mathrm{x}}[x \in(\mathrm{b}, \mathrm{c}, \mathrm{d}, \mathrm{e})]$ are the coefficients to be estimated. An elaborate description of variables is presented in Table 1 . The estimated coefficients represent the percentage change of bilateral trade along with a unit variation in the independent variable [36]. The coefficient can be interpreted as an elasticity directly when the independent variable is showed in logs; and when the variable is a dummy, it needs to be transformed in order to be interpreted as elasticity as follows: elasticity $=\exp (\beta)-$ 1. The econometric software STATA 13.0 has been applied in the estimation of all count models. 
Table 1. Variable specification in the gravity equation.

\begin{tabular}{|c|c|c|}
\hline Symbols of variables & Expected symbol & Specification \\
\hline$X_{i j t \_p}, X_{i j t \_r}, X_{i j t_{-} s}, X_{i j t \_f}$ & & Value of the bilateral trade flow between $i$ and $j$ for four kinds of vegetable oils in year $t$ \\
\hline$G D P_{i t}$ & Positive & Exporter's GDP in year $t$, representing supply capacity of exporting countries, in logs \\
\hline$G D P_{j t}$ & Positive & Importer's GDP in year $t$, representing demand capacity of importing countries, in logs \\
\hline$D I S_{i j}$ & Negative & Great circle distance between the capital cities of country $i$ and $j$, in logs \\
\hline$I N C_{i j t}$ & Negative & $\begin{array}{l}\text { Square of the difference in per capita income between countries } i \text { and } j \text {, in logs: } \ln \left[\left(G D P_{i t}-\right.\right. \\
\left.\left.G D P_{j t}\right)^{2}\right] \text {. GDP per capita is measured in current US dollars. }\end{array}$ \\
\hline$R A T E_{i j t}$ & Uncertain & $\begin{array}{l}\text { Exporter } i \text { 's currency/importer } j \text { 's currency, in year } t \text { in logs. Exchange rate is measured in } \\
\text { Local Currency Units (LCU) per US dollars, period average. }\end{array}$ \\
\hline$S E E D_{i j t}$ & Negative & Value of bilateral trade flow between $i$ and $j$ for four main vegetable oilseeds in year $t$ \\
\hline$F T A_{i j t}$ & Positive & $\begin{array}{l}\text { Dummy variable which equals } 1 \text { whenever } i \text { and } j \text { have belonged to the same bilateral or } \\
\text { regional FTA in year } t \text {, and } 0 \text { otherwise }\end{array}$ \\
\hline$L A N G_{i j}$ & Positive & $\begin{array}{l}\text { Dummy variable which equals } 1 \text { whenever } 9 \% \text { or more of the population in both countries } \\
\text { speak the same language, and } 0 \text { otherwise }\end{array}$ \\
\hline$C O L_{i j}$ & Positive & $\begin{array}{l}\text { Dummy variable which equals } 1 \text { if } i \text { and } j \text { have established colonial linkage since 1945, and } \\
0 \text { otherwise }\end{array}$ \\
\hline$B O R_{i j}$ & Positive & Dummy variable which equals 1 when $i$ and $j$ share a border, and 0 otherwise \\
\hline
\end{tabular}

\subsection{Data}

The balanced panel dataset spans 80 countries for the period from 2000 to 2013. In order to remove selection bias, our data sample includes low-, lower middle-, upper middle-, and high-income countries based on the classification by World Bank. The 80 countries account for more than $84 \%$ of the world's cross-border trade in vegetable oil and $96 \%$ of global GDP.

\subsubsection{Discrepancy in Bilateral Trade Data}

Data on bilateral trade for vegetable oil and vegetable oilseeds are taken from the United Nations Commodity Trade Statistics (UN Statistical Office, 2014) database, UN Comtrade, the agency relies on the trade statistics reported by its member countries. Therefore, two observations will be existed in UN Comtrade for every bilateral trade flow, one obtained from the exporting country and the other from the importing country. The obvious discrepancy in these reports is the value that what exporting country says it sends to importing country is not the same as what importing country says it receives from exporting country. This is because reported bilateral trade flows have not been reconciled. In order to solve the problem of discrepancies in reported data in UN Comtrade, the principle of using aggregate imports as benchmarks has been adopted when adjusting bilateral by exports Statistics Canada's World Trade Analyzer. Importing country has an incentive to record imports accurately because tariff revenues has to be collected and it is usually agreed that reported imports are more reliable than reported exports [37].

\subsubsection{Other Data}

The data on GDP, GDP per capita in each country were obtained from the World Development Indicators, World Bank (2014) and OECD National Accounts data files.

Distances between capital cities of bilateral trade were calculated by using Great Circle Mapper, a website for generating maps of great circle routes (shortest paths between two points on a sphere's surface; technically geodesic paths when referring to the earth).

The data about exchange rate was obtained International Monetary Fund, International Financial Statistics Database (2014).

Information about the existence of bilateral and regional FTAs was obtained from List of bilateral free trade agreements in Wikipedia.

Data about language similarity and colonial heritage were obtained from Centre d'Etudes Prospectives et d'Informations Internationales (CEPII), The CEPII Geo Dist dataset (2014).

Information about common borders is derived from Google maps. 


\section{Results and Discussion}

Now, we are focusing on different drivers that either deter or aid partner trade in four different vegetable oils and comparing the impact difference. We estimate gravity Equations (6)-(9) by using the balanced panel data of PPML model. The result of the four vegetable oils trade is shown in Table 2.

The $G D P_{i t}$ and $G D P_{j t}$ coefficients have a positive influence on all the four kinds of vegetable oil trade and are statistically significant except the $G D P_{i t}$ variable is not influential on the soybean oil trade and is statistically insignificant. The influence of importer's economic scale is significantly larger than the influence of exporter's, which is also matching the overlapping demand theory.

As expected, the distance variables have negative symbols and are statistically significant for palm oil, rapeseed oil and sunflower seed oil trade, a result which is supported by the majority of gravity studies on agricultural food. This result indicates that distance deters trade as trade barrier. Also, comparing the elasticity of each vegetable oil, palm oil has a greater competition and less substitutability in demand within these three vegetable oils, the reason may be palm oil is produced in tropical and it is hard to be replaced by vegetable oils which are produced in other parts of the earth. However, the distance coefficient has positive symbol for soybean oil trade and is statistically significant at one percent level. This contrary result may indicate that for soybean oil, the distance does not influence trade.

Model results show that income differences between two countries generally decrease bilateral trade in palm oil, soybean oil and sunflower seed oil, palm oil trade has the biggest elasticity among those three vegetable oils, which means income differences increase $1 \%$, palm oil trade decrease the most among three vegetable oils. It is also proved the standpoint by Dalgin et al. we discussed before. We can analyze results from different side which is the vegetable oil trade decrease at the same point, income difference between trading partners on palm oil increase the most, that is, palm oil is the last luxuries vegetable oil within those three. The price of palm oil is the cheapest in those three in the world in reality. On the other hand, $I N C_{i j t}$ parameter estimate in rapeseed oil is

Table 2. Estimated parameters of the gravity equation of four vegetable oils with PPML model.

\begin{tabular}{|c|c|c|c|c|c|}
\hline Variables & Symbols & Palm oil & Rapeseed oil & Soybean oil & Sunflower seed oil \\
\hline Exporter's GDP & $\ln G D P_{i t}$ & $\begin{array}{c}0.227^{* * *} \\
(4.44)\end{array}$ & $\begin{array}{l}0.449^{* * *} \\
(12.46)\end{array}$ & $\begin{array}{c}0.0620 \\
(1.30)\end{array}$ & $\begin{array}{l}0.134^{* *} \\
(2.10)\end{array}$ \\
\hline Importer’s GDP & $\ln G D P_{j t}$ & $\begin{array}{l}0.420^{* * *} \\
(17.23)\end{array}$ & $\begin{array}{l}0.847^{* * *} \\
(30.40)\end{array}$ & $\begin{array}{l}0.465^{* * *} \\
(21.67)\end{array}$ & $\begin{array}{l}0.452^{* * *} \\
(19.76)\end{array}$ \\
\hline Distance & $\ln D I S_{i j}$ & $\begin{array}{c}-0.119^{* *} \\
(-2.14)\end{array}$ & $\begin{array}{l}-1.051^{* * *} \\
(-27.57)\end{array}$ & $\begin{array}{c}0.317^{* * *} \\
(4.21)\end{array}$ & $\begin{array}{l}-1.265^{* * *} \\
(-33.76)\end{array}$ \\
\hline Income differences & $\ln I N C_{i j t}$ & $\begin{array}{c}-0.188^{* * *} \\
(-15.82)\end{array}$ & $\begin{array}{c}-0.00822 \\
(-0.56)\end{array}$ & $\begin{array}{l}-0.105^{* * *} \\
(-15.30)\end{array}$ & $\begin{array}{c}-0.130^{* * *} \\
(-11.44)\end{array}$ \\
\hline Exchange rate & $\ln R A T E_{i j t}$ & $\begin{array}{c}-0.000261 \\
(-0.01)\end{array}$ & $\begin{array}{c}0.0282 \\
(1.21)\end{array}$ & $\begin{array}{c}-0.00273 \\
(-0.28)\end{array}$ & $\begin{array}{c}0.00395 \\
(0.31)\end{array}$ \\
\hline Oilseed trade & $\ln S E E D_{i j t}$ & $\begin{array}{c}0.162^{* * *} \\
(4.02)\end{array}$ & $\begin{array}{l}0.479^{* * *} \\
(11.87)\end{array}$ & $\begin{array}{c}0.360^{* * * *} \\
(8.42)\end{array}$ & $\begin{array}{c}0.312^{* * *} \\
(6.75)\end{array}$ \\
\hline Mutual FTA membership & $F T A_{i j t}$ & $\begin{array}{c}0.571^{* * * *} \\
(3.19)\end{array}$ & $\begin{array}{c}0.194^{* * *} \\
(2.65)\end{array}$ & $\begin{array}{l}0.154^{* *} \\
(2.53)\end{array}$ & $\begin{array}{c}-1.288^{* * *} \\
(-14.23)\end{array}$ \\
\hline Language similarity & $L A N G_{i j}$ & $\begin{array}{l}0.273^{*} \\
(1.71)\end{array}$ & $\begin{array}{l}0.159^{* *} \\
(2.08)\end{array}$ & $\begin{array}{c}0.494^{* * *} \\
(8.10)\end{array}$ & $\begin{array}{c}-0.0840 \\
(-1.02)\end{array}$ \\
\hline Colonial heritage & $C O L_{i j}$ & $\begin{array}{c}1.105^{* * *} \\
(4.92)\end{array}$ & $\begin{array}{c}-1.096^{* * *} \\
(-4.07)\end{array}$ & $\begin{array}{l}-1.931^{* * *} \\
(-12.64)\end{array}$ & $\begin{array}{l}0.121 \\
(0.67)\end{array}$ \\
\hline Common border & $B O R_{i j}$ & $\begin{array}{c}-0.0602 \\
(-0.38)\end{array}$ & $\begin{array}{l}1.024^{* * *} \\
(14.14)\end{array}$ & $\begin{array}{l}1.249^{* * *} \\
(12.91)\end{array}$ & $\begin{array}{c}0.0405 \\
(0.49)\end{array}$ \\
\hline constant & & $\begin{array}{l}-1.515 \\
(-1.43)\end{array}$ & $\begin{array}{l}-23.01^{* * *} \\
(-19.38)\end{array}$ & $\begin{array}{c}-7.793^{* * *} \\
(-7.23)\end{array}$ & $\begin{array}{c}4.378^{* * *} \\
(7.06)\end{array}$ \\
\hline $\mathrm{R}^{2}$ & & 0.015 & 0.68 & 0.04 & 0.09 \\
\hline Number of observations & & 88,480 & 88,480 & 88,480 & 88,480 \\
\hline
\end{tabular}

Notes: Results for the year fixed effects are not reported for space saving reason. Parentheses denote t-statistics.

${ }^{* * *},{ }^{* *}$, and ${ }^{*}$ denote significance at $1 \%, 5 \%$, and $10 \%$ level, respectively. 
statistically insignificant at any lever. The reason could be the sample capacity of rapeseed oil is the least within the four vegetable oils and it may cause inaccurate estimate.

Results show that $R A T E_{i j t}$ coefficients are not statistically significant at any lever in any vegetable oils. The influence of bilateral exchange rate on vegetable oil between exporter and importer may compensate with each other so it does not influence trade anymore.

Unsurprisingly, model results show positive impact of oilseeds trade on trade in four vegetable oils and the $S E E D_{i j t}$ coefficients are statistically significant at $1 \%$. Therefore, substitute relationships between vegetable oils and vegetable oilseeds in the four vegetable oils trade do not exist. From the $S E E D_{i j t}$ coefficients we can see that trade in vegetable oilseeds increase $1 \%$, rapeseed oil trade increase the most among those four kinds of vegetable oils. When we quote the reason that part of the vegetable oilseeds of countries imports are used to export to other countries, if the importing country imports a certain amount of oilseeds, it exports rapeseed oil the most, which would be rapeseed has the most oil yield within four oilseeds.

Surprisingly, model results show negative impact of bilateral FTAs on trade in sunflower seed oil and $F T A_{i j t}$ coefficient is statistically significant at $1 \%$ lever. Mutual FTA membership does increase partner trade in palm oil, rapeseed oil and soybean oil. Estimate shows that mutual membership in a FTA generated, on average, 77 percent more palm oil trade between $i$ to $j$ in comparison with the absence of a common FTA membership $\{[\exp (0.571)-1]=0.77\}$. By contrast, $21 \%$ and $17 \%$ more rapeseed oil and soybean oil trade in partner countries separately when they belong to a common FTA than they do not belong to the same FTA $\{[\exp (0.194)-1]$ $=0.21\} ;\{[\exp (0.154)-1]=0.17\}$. Above all, joining the same FTA could lower the most trade costs between memberships in palm oil trade. Take the exporting palm oil in South East Asia for example; South East Asia is the major palm oil exporter in the world, South East Asia Regional Trade Agreement has a positive dynamic effect on palm oil trade flow (Pujiati et al., 2014).

Our results provide confirmation that language similarity increases trade in palm oil, rapeseed oil and soybean oil as expected. The ability to communicate in the same language has a bigger trade effect in soybean oil which is result in that soybean could be the most widely traded vegetable oil among those four and it needs facilitate communication the most during economic transactions. The model results show little impact of Language similarity on trade in sunflower seed oil and $L A N G_{i j}$ coefficient is statistically insignificant at any lever.

Model results show that the sharing of a common colonial heritage has a positive impact only on palm oil, but it has a more pronounced impact on trade than language similarity. The possible reason for this could be palm oil is a product of tropical plant which is different from other vegetable oils could be produced by plants in broader area on earth, that is, this kind of oil is exported in certain countries. If there is a past relationship between partner countries, the trade could be more facilitate with each other than they don't share a common past relationship. $C O L_{i j}$ coefficients are negative and statistically significant at $1 \%$ lever in rapeseed oil and soybean oil trade, the coefficient is statistically insignificant at any lever in sunflower seed oil trade.

Sharing a common border does not impart a trade advantage in each kind of vegetable oils. It only has a positive impact on rapeseed oil and soybean oil trade and notable exceptions include trade in palm oil and sunflower seed oil. The parameter estimates for $B O R_{i j}$ are not significantly different from zero in palm oil and sunflower oil trade. The conclusion is that trade in rapeseed oil and soybean oil are still influenced by regional factor while palm oil and sunflower seed oil trade are not influenced by location, which is saying that palm oil and sunflower seed oil have a higher value and the distance does not influenced their trade.

\section{Conclusions}

This study employs balanced panel data on global four kinds of vegetable oil trade flows between 80 countries for the period from 2000 to 2013 combined with the generalized theoretically consistent gravity framework, uses the Pseudo Poisson maximum likelihood (PPML) estimator to measure the influence of the various factors driving the direction and volume of trade.

In the vegetable oils trade model, geographical factors do not influence trade in such significant way. Distance is not always impede trade in four kinds of vegetable oils, the empirical results show that soybean oil trade increases as the distance becomes further with trading partners. Common border encourages bilateral trade only in rapeseed oil and soybean oil. Synthesizes each kind of geographical factor, rapeseed oil trade is the most impacted by geography among four main vegetable oils. From the historical aspect, palm oil trade is the only one influenced by both colonial heritage and language similarity, however, it gets less positive effect from language 
similarity than soybean oil and rapeseed oil trade. Palm oil trade decrease the most when income differences increase $1 \%$, which is saying that palm oil is the last luxuries vegetable oils among them. The result shows the evidence that mutual FTA membership increases partner trade in pam oil, rapeseed oil and soybean oil but has negative impact on members' trade with each other in sunflower seed oil. Vegetable oilseeds trade still has a positive impact on four main vegetable oils trade and rapeseed oil trade increase the most among those four kinds of vegetable oils when vegetable oilseeds increase at the same lever.

Restricted by various factors, this research on bilateral trade in vegetable oil has the following flaws at least: one is we ignored some impact factors may affect bilateral vegetable oil trade when model specification is designed, for example, because of unable to uniform four kinds of vegetable oil tariffs, the possible influence by applied tariff protection, including specific, variable and compound tariffs, and tariff-rate quotas on vegetable oil trade has been ignored. And some important factors ignored which are hard to quantify including macroeconomic policy and institutional environment of trade partner may impact vegetable oil trade on the man-made aspect. The other is we don't do the meaningful vertical comparison (year) on the factors influencing vegetable oil trade because of using the panel data. We will resolve these deficiencies gradually in the following researches.

\section{References}

[1] Josling, T., Tangermann, S. and Warley, T.K. (1996) Agriculture in the GATT. Macmillan and St. Martin’s Press, New York. http://dx.doi.org/10.1057/9780230378902

[2] Meilke, K., Wensley, M. and Cluff, M. (2001) The Impact of Trade Liberalization on the International Oilseed Complex. Review of Agricultural Economics, 1, 2-17. http://dx.doi.org/10.1111/1058-7195.00042

[3] In, F. and Inder, B. (1997) Long-Run Relationships between World Vegetable Oil Prices. The Australian Journal of Agricultural and Resource Economics, 4, 455-470. http://dx.doi.org/10.1111/1467-8489.00024

[4] Vollrath, T.L., Gehlhar, M.J. and Hallahan C.B. (2009) Bilateral Import Protection, Free Trade Agreements, and Other Factors Influencing Trade Flows in Agriculture and Clothing. Journal of Agricultural Economics, 2, 298-317. http://dx.doi.org/10.1111/j.1477-9552.2008.00186.x

[5] Robinson, S., Burfisher, M.E., Hinojosa-Ojeda, R., et al. (1993) Agricultural Policies and Migration in a US-Mexico Free Trade Area: A Computable General Equilibrium Analysis. Journal of Policy Modeling, 5-6, 673-701. http://dx.doi.org/10.1016/0161-8938(93)90009-F

[6] Park, I. (2006) East Asian Regional Trade Agreements: Do They Promote Global Free Trade? Pacific Economic Review, 4, 547-568. http://dx.doi.org/10.1111/j.1468-0106.2006.00334.x

[7] Baier, S.L. and Bergstrand, J.H. (2004) Economic Determinants of Free Trade Agreements. Journal of International Economics, 1, 29-63. http://dx.doi.org/10.1016/S0022-1996(03)00079-5

[8] Pujiati, R., Firdaus, M., Adhi, A.K., et al. (2014) The Impact of Regional Trade Agreements to the Commodity Trade Flows. Forum Agribisnis, 2, 193-206.

[9] Zahniser, S.S., Pick, D., Pompelli, G., et al. (2002) Regionalism in the Western Hemisphere and Its Impact on U.S. Agricultural Exports: AGravity-Model Analysis. American Journal of Agricultural Economics, 3, 791-797. http://dx.doi.org/10.1111/1467-8276.00338

[10] Kavallari, A., Maas, S. and Schmitz, P.M. (2010) Evidence on Euromediterranean Trade Integration: The Case of German Olive Oil Imports. German Journal of Agricultural Economics, 1, 40-46.

[11] Vlontzos, G. and Duquenne, M.N. (2008) Greek Olive Oil: How Can Its International Market Potential Be Realized? The Estey Centre Journal of International Law and Trade Policy, 9, 32-47.

[12] Röttgers, D., Faße, A. and Grote, U. (2009) Analysing the EU Canola Oil Trade with Developing Countries: A Gravity Model Approach. Conference on International Research on Food Security, Natural Resource Management and Rural Development, Hamburg, 6-8 October 2009.

[13] Tinbergen, J. (1962) Shaping the World Economy: Suggestions for an International Economic Policy. Twentieth Century Fund, New York.

[14] Pullianen, K.A. (1963) A World Trade Study: An Econometric Model of the Patterns of the Commodity Flows in International Trade 1948-1960. Economiska Samfundets Tidskrift, 16, 78-91.

[15] Anderson, J.E. (1979) A Theoretical Foundation for the Gravity Equation. American Economic Review, 69, $106-116$.

[16] Helpman, E. and Krugman, P.R. (1985) Market Structure and Foreign Trade: Increasing Returns, Imperfect Competition, and the International Economy. MIT Press, Cambridge, MA.

[17] Bergstrand, J.H. (1985) The Gravity Equation in International Trade: Some Microeconomic Foundations and Empirical 
Evidence. The Review of Economics and Statistics, 67, 474-481. http://dx.doi.org/10.2307/1925976

[18] Bergstrand, J.H. (1989) The Generalized Gravity Equation, Monopolistic Competition and the Factor-Proportions Theory in International Trade. The Review of Economics and Statistics, 71, 143-153. http://dx.doi.org/10.2307/1928061

[19] Deardorff, A.V. (1998) Determinants of Bilateral Trade Flows: Does Gravity Work in a Neoclassical World. In: Frankel, J.A., Ed., The Regionalization of the World Economy, The University of Chicago Press, Chicago.

[20] Evenett, S.J. and Keller, W. (2002) On Theories Explaining the Success of the Gravity Equation. Journal of Political Economy, 110, 281-316. http://dx.doi.org/10.1086/338746

[21] Anderson, J.E. and van Wincoop, E. (2003) Gravity with Gravitas: A Solution to the Border Puzzle. American Economic Review, 93, 170-192. http://dx.doi.org/10.1257/000282803321455214

[22] Anderson, J.E. and van Wincoop, E. (2004) Trade Costs. Journal of Economic Literature, 42, 691-751. http://dx.doi.org/10.1257/0022051042177649

[23] Feenstra, R.C. (2004) Advanced International Trade: Theory and Evidence. Princeton University Press, Princeton.

[24] Frankel, J., Stein, E. and Wei, S.J. (1993) Continental Trading Blocs: Are They Natural or Supernatural? University of Chicago Press, Chicago. http://dx.doi.org/10.3386/w4588

[25] Philippidis, G., Resano-Ezcaray, H. and Sanjuán-López, A.I. (2013) Capturing Zero-Trade Values in Gravity Equations of Trade: An Analysis of Protectionism in Agro-Food Sectors. Agricultural Economics, 44, 141-159. http://dx.doi.org/10.1111/agec.12000

[26] Burger, M.J., van Oort, F.G. and Linders, G.M. (2009) On the Specification of the Gravity Model of Trade: Zeros, Excess Zeros and Zero-Inflated Estimation. Spatial Economic Analysis, 4, 167-190. http://dx.doi.org/10.1080/17421770902834327

[27] Wooldridge, J.M. (2002) Econometric Analysis of Cross Section and Panel Data. MIT Press, Cambridge, MA.

[28] Santos Silva, J.M.C. and Tenreyro, S. (2006) The Log of Gravity. The Review of Economics and Statistics, 88, 641-658. http://dx.doi.org/10.1162/rest.88.4.641

[29] Marlin, W. and Pham, C. (2008) Estimating the Gravity Model When Zero Trade Flows Are Frequent. Working Paper, World Bank, Washington DC.

[30] Eichengreen, B. and Irwin, D.A. (1998) The Role of History in Bilateral Trade Flows. In: Frankel, J., Ed., The Regionalization of the World Economy, National Bureau of Economic Research, University of Chicago Press, Chicago.

[31] Santos Silva, J.M.C. and Tenreyro, S. (2011) Further Simulation Evidence on the Performance of the Poisson Pseudo-Maximum Likelihood Estimator. Economics Letters, 112, 220-222. http://dx.doi.org/10.1016/j.econlet.2011.05.008

[32] Francois, J. and Manchin, M. (2006) Institutional Quality, Infrastructure and the Propensity to Export. Working Paper, Centro Studi Luca D’Agliano, Università degli Studi di Milano, Milano.

[33] Balu, N. and Ismail, N. (2011) Free Trade Agreement-The Way Forward for the Malaysian Palm Oil Industry. Oil Palm Industry Economic Journal, 2, 26-35.

[34] Linder, S.B. (1961) An Essay on Trade and Transformation. Almqvist \& Wiksells, Stockholm.

[35] Dalgin, M., Trindade, V. and Mitra, D. (2008) Inequality, Nonhomothetic Preferences, and Trade: A Gravity Approach. Southern Economic Journal, 74, 747-774.

[36] Cameron, A.C. and Trivedi, P.K. (1998) Regression Analysis of Count Data. Cambridge University Press, Cambridge. http://dx.doi.org/10.1017/CBO9780511814365

[37] Gehlhar, M. (1996) Reconciling Bilateral Trade Data for Use in GTAP. Purdue University, Center for Global Trade Analysis, Global Trade Analysis Project, Technical Papers, Statistics Canada. 